\title{
Deteksi Radar Pasif menggunakan GNU Radio dan SDR pada Frekuensi Televisi
}

\section{YONATAN EDWIN MARPAUNG, ALOYSIUS ADYA PRAMUDITA, ERFANSYAH ALI}

\author{
Fakultas Teknik Elektro, Universitas Telkom \\ Email : yonatanedwinmarpaung@gmail.com \\ Received 19 Maret 2020 | Revised 8 April 2020 | Accepted 25 Juli 2020
}

\begin{abstract}
ABSTRAK
Radar pasif adalah salah satu jenis sistem radar bistatic dimana transmitter dan receiver berada di tempat berbeda. Sistem radar pasif dapat memaanfaatkan frekuensi siaran televisi yang tersedia sebagai sumber transmitter. Pada penelitian ini, radar pasif dibuat dengan Sofware Defined Radio (SDR) sebagai sistem komunikasi yang dapat mengkofigurasi penerima televisi digital sdr-dongle RTL2832U yang dimodifikasi dan perangkat lunak GNU Radio. Hasil pengujian delay pada gelombang 1,2,3 untuk objek manusia adalah 0,192, 0,36 dan 0,53 detik, untuk objek sepeda adalah 0,332, 0,5 dan 0,67, untuk objek motor adalah 0,422, 0,69 dan 0,86 detik, untuk objek mobil adalah 0,538, 0,7 dan 0,87 detik sehingga dapat disimpulkan bahwa sistem radar pasif yang dirancang dapat mendeteksi benda bergerak dimana pegerakan target menyebabkan pergeseran puncak Cross-Correlation.
\end{abstract}

Kata kunci: Radar Pasif, Cross-Correlation, SDR, Frekuensi Televisi, RTL2832U

\begin{abstract}
Passive radar is a type of bistatic radar system where the transmitter and receiver are in different places. Passive radar systems can utilize the available television broadcast frequencies as transmitter sources. In this study, passive radar is made with Software Defined Radio (SDR) as a communication system that can configure a modified RTL2832U sdr-dongle digital television receiver and GNU Radio software. The delay test results on waves 1,2,3 for human objects are 0.192, 0.36 and 0.53 seconds, for bicycle objects are $0.332,0.5$ and 0.67 , for motor objects are $0.422,0.69$ and 0.86 seconds, for car objects are $0.538,0.7$ and 0.87 seconds so it can be concluded that the passive radar system is designed to detect moving objects where moving targets causes a shift in the peak of Cross-Correlation.
\end{abstract}

Keywords: Passive Radar, Cross-Correlation, SDR, Television Frequency, RTL2832U 
Marpaung, dkk

\section{PENDAHULUAN}

Radar adalah sistem elektromagnetik untuk deteksi lokasi benda-benda, beroperasi dengan cara memancarkan gelombang elektromagnetik ke segala arah (Skolnik, 1990). Ketika gelombang sinyal terkena suatu benda, gelombang sinyal tersebut akan memantul dan kembali ke antena perima. Dengan mekanisme tersebut, pengguna radar dapat mengetahui jarak, arah, dan kecepatan dari benda yang memantulkan gelombang tersebut (Skolnik, 2002). Namun dibalik kemampuannya yang dapat melacak objek, radar konvesional juga memiliki kelemahan, yaitu saat radar memancarkan sinyal, radar tersebut dapat dilacak oleh radar lainnya (Rahman, 2019). Oleh karena itu, dikembangkanlah radar pasif (Griffiths, Passive Bistatic Radar, 2014).

Radar pasif merupakan radar yang terdiri dari beberapa receiver (Griffiths, Passive Bistatic Radar, 2014). Prinsip kerja receiver radar pasif menggunakan prinsip triangulasi untuk menentukan posisi, ketinggian, kecepatan, dan arah pergerakan sasaran yang dideteksi. Keuntungan menggunakan radar pasif adalah antara lain mampu mendeteksi sasaran dalam jarak jauh tanpa diketahui (senyap) karena tidak memancarkan sinyal radar, mampu mendeteksi emisi di daratan dan lautan secara senyap, bekerja secara rahasia, relatif murah dan mudah dirawat (Willis, 2005). Untuk menjalankan sebuah radar pasif dibutuhkan beberapa Software Defined Radio (SDR) (Saputera, Herdiana, Madinawati, Suksmono, \& Munir, 2015). Software Defined Radio (SDR) adalah sistem komunikasi radio dimana komponen perangkat keras digantikan perangkat lunak (Hosking, 2011).

Ruang lingkup penelitian ini mencakup 4 ruang lingkup yaitu radar pasif, frekuensi televisi, SDR, dan Cross-Correlation. Menurut jurnal penelitian oleh Feng, dengan range resolusi dan bandwidth yang rendah berbagai target pada jarak jauh dan dekat dapat terdeteksi, analisis target bergerak dapat mendeteksi pesawat pada jarak $4 \mathrm{~km}$ dan mobil pada jarak dekat serta jangkauan radar pasif tidak dapat ditentukan (Feng, Cherniak, \& Friedt, 2018). Jurnal kedua oleh Sebastiaan Heunis dilakukan penelitian radar pasif menggunakan GNU Radio, USRP, dan 4 antena yagi dapat mendeteksi pesawat penumpang komersial dalam jarak dekat dengan memanfaatkan sinyal FM. Target dapat dideteksi dengan mengkorelasi silang antara surveillance signal dengan reference signal (Heunis, Paichard, \& Inggs, 2011). Jurnal ketiga oleh Amerigo Capria menyatakan bahwa secara khusus, bahwa pemancar DVB-T adalah iluminator yang cocok untuk mendeteksi kendaraan dengan kecepatan yang berbeda (Capria, et al., 2010). Jurnal keempat oleh Rafael Gonçalves Licursi de Mello menyatakan bahwa sudah dimungkinkan untuk merancang detektor radar dengan teknologi perangkat tablet dan SDR saat ini. Dengan NooElec RTL-SDR dan perangkat tablet Microsoft Surface Pro 4 yang menjalankan Matlab, percobaan di mana sinyal berdenyut dari Rohde \& Schwarz R\&S SMA 100A dan Ettus Research USRP B200 SDR diterima, diproses dan diidentifikasi dilakukan (Mello, Sousa, \& junqueira, 2017). Penelitian yang dilakukan pada saat ini menggunakan antena indoor berbeda dengan yang digunakan pada penelitian yang dilakukan sebelumnya dimana digunakan antena outdoor.

Penelitian ini difokuskan pada pengujian radar pasif yang diimplementasikan berbasis SDR dengan memanfaatkan RTL-SDR dongle 24-1700 MHz Realtek RTL2832U R820T2 yang menggunakan GNU Radio sebagai platform radar pasif. Pengujian dilakukan dengan mengamati pergeseran puncak korelasi untuk mendeteksi kecepatan objek. 


\section{METODOLOGI PENELITIAN}

\subsection{Prinsip Skenario}

Target bergerak dideteksi dengan memanfaatkan sinyal transmit dari suatu pemancar. Dari sinyal transmit yang disebarkan secara omnidirectional, receiver akan menerima dua macam sinyal yaitu sinyal langsung dan sinyal pantul. Perbedaan sinyal langsung dan sinyal pantul terdapat pada waktu penerimaannya atau delay. Delaytersebut menyebabkan pergeseran dari puncak korelasi silang. Dari hasil pergeseran puncak korelasi dapat diidentifikasi bahwa ada benda bergerak pada radius Reference Antenna Receiver (Griffiths, Passive Bistatic Radar, 2014).

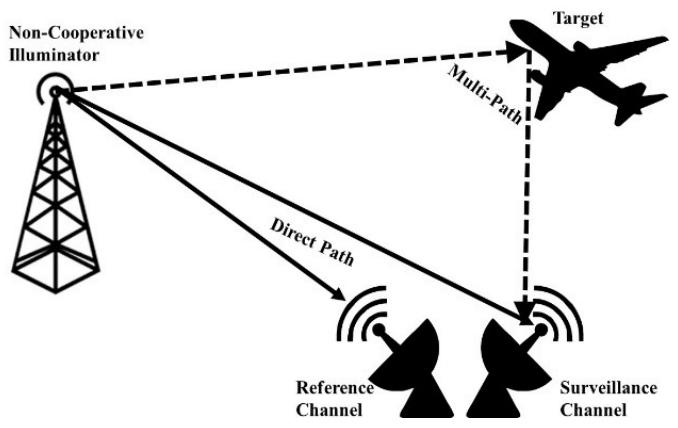

Gambar 1. Konfigurasi Radar Pasif (Griffiths, Passive Bistatic Radar, 2014).

Persamaan sinyal pada antenna surveillance $x_{s}$ ditunjukan pada Persamaan (1) :

$$
x_{s}(n)=\gamma p(n)+\alpha p(n-\tau) \exp \left(j \Omega_{d} n\right)+\omega(n)
$$

Dimana $p(n)$ adalah sinyal yang ditransmisikan dari non-cooperative illuminators of opportunity (IO), y adalah parameter untuk melakukan scaling pada kanal propagasi yang didapat secara langsung dari IO ke receiver. $\tau$ adalah delay propagasi yang dihasilkan dari pantulan target. $\alpha$ adalah parameter untuk melakukan scaling terhadap pantulan target dan propagasi kanal. $\Omega_{d}$ adalah Frekuensi Doppler ternormalisasi, dan $\omega(n)$ menyatakan thermal noise yang dimodelkan identik dan terdistribusi secara circular Complex Gaussian dengan nilai mean zero dan variance, disini ditinjau skenario yang lebih realistis, dengan sisa sinyal direct path yang diakibatkan dari imperfect interference (Liu, Li, \& Himed, 2015).

Refrence Channel (RC) biasanya menggunakan direction antenna yang diarahkan pada IO, dan sinyal yang diterima $x_{r}$ dapat diekspresikan dengan Persamaan (2)

$$
x_{r}(n)=\beta p(n)+v(n),
$$

dimana $\beta$ adalah faktor pengali untuk menghitung efek kanal propagasi dari IO ke antenna dalam RC, dan $v(n)$ adalah Thermal noise yang terditribusi secara circular complex Gaussian. Akan masuk akal jika, pengasumsian Thermal noise $v(n)$ dan $\omega(n)$ bersifat independen.

Asumsikan null hypothesis $\left(H_{0}\right)$, seperti data yang ada di Surveillance Channel (SC), bebas dari echo target seperti pada Persamaan (3), dimana hipotesis alternatif adalah sebaliknya. Jadi, permasalah passive detection dapat dirumuskan dengan binary hypothesis test $\left(H_{1}\right)$ seperti Persamaan (4) (Liu, Li, \& Himed, 2015). 


$$
\begin{gathered}
H_{0}:\left\{\begin{array}{l}
x_{r}(n)=\beta p(n)+v(n) \\
x_{s}(n)=\gamma p(n)+w(n)
\end{array}\right. \\
H_{1}:\left\{\begin{array}{c}
x_{r}(n)=\beta p(n)+v(n) \\
x_{s}(n)=\gamma p(n)+\alpha p(n-\tau) \exp \left(j \Omega_{d} n\right)+\omega(n)
\end{array}\right.
\end{gathered}
$$

Sistem radar pasif dapat mendeteksi dan melacak target yang diminati dengan mengeksploitasi IO. Dalam radar pasif, lokasi dan bentuk gelombang yang digunakan oleh IO tidak lagi terkendali. Dengan demikian, sistem radar pasif sering membutuhkan saluran terpisah tambahan yang disebut dengan RC, untuk mengukur sinyal yang ditransmisikan dari IO untuk berfungsi sebagai referensi. Delay-Doppler Cross-Correlation (CC) merupakan strategi pendeteksian antara data yang diterima dalam RC dan SC. Keuntungan utama dari CC terletak pada kesederhanaan implementasi dan persyaratan tidak ada pengetahuan sebelumnya tentang bentuk gelombang yang ditransmisikan (Liu, Li, \& Himed, 2015).

Transformasi Fourier, serta rumus yang menautkan bentuk gelombang dalam waktu ke spektrumnya, juga digunakan dalam statistik. Transformasi Fourier yang kompleks dapat dikalikan bersama hanya untuk konvolusi atau dengan complex conjugate. Seperti dalam perhitungan daya arus bolak balik, yang disebut korelasi. Korelasi digunakan untuk mencocokan sinyal dengan salinan referensi yang disimpan dalam memori. Rumus CrossCorrelation ditunjukan pada Persamaan (5) (Proakis \& Manolakis, 2007).

$$
\mathrm{h}(\mathrm{t})=f(t) \star g(t)=\int_{-\infty}^{+\infty} f *(t) g(u-t) d u \text { or } \int_{-\infty}^{+\infty} f(u-t) g *(t) d u
$$

dimana five-pointed star berarti "correlated with", $f *(t)$ adalah complex conjugate dari $f(t)$ dan $g *(u-t)$ adalah complex conjugate dari $g(u-t)$. Dalam Transformasi Fourier, Transformasi dari Cross-Correlation ditunjukan pada Persamaan (6)

$$
H(f)=F *(f) G(f)=F(f) G *(f)
$$

dimana $F *(f)$ adalah complex conjugate dari $F(f)$ dan $G *(f)$ adalah complex conjugate dari $G(f)$ (Proakis \& Manolakis, 2007).

\subsection{Model Skenario}

Pada model seperti yang ditunjukan pada Gambar 2, setiap bagian memiliki peranannya masing-masing, UHF dan VHF Transmitter sebagai sumber sinyal yang dimanfaatkan oleh sistem radar pasif (Griffiths \& Baker, An Introduction to Passive Radar, 2017), mobil sebagai target yang diamati, Reference Antenna Receiver sebagai antena yang mengarah ke sumber sinyal, Surveillance Antenna Receiver sebagai antena yang mengarah ke tempat yang diamati/tempat dimana target berada, Cross-Correlation sebagai penggabung dua buah sinyal yang diterima dari Reference Antenna Receiver dan Surveillance Antenna Receiver, dan GNU Radio sebagai software untuk memproses sinyal yang diterima yang akan ditampilkan pada monitor. 


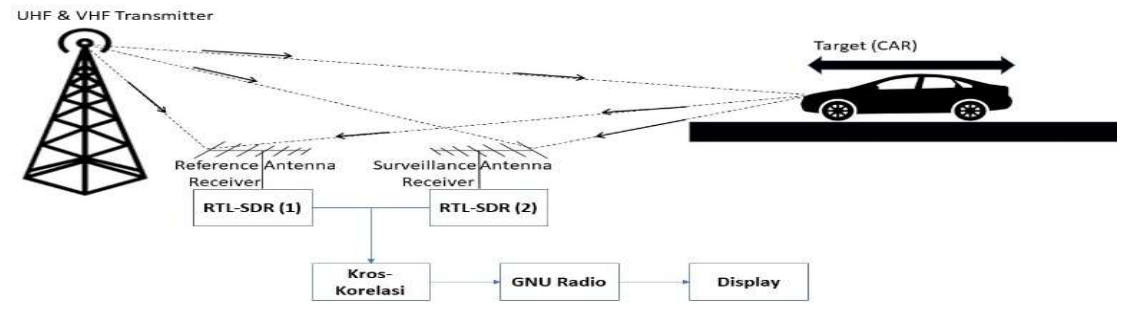

Gambar 2. Model Perancangan Sistem Radar Pasif

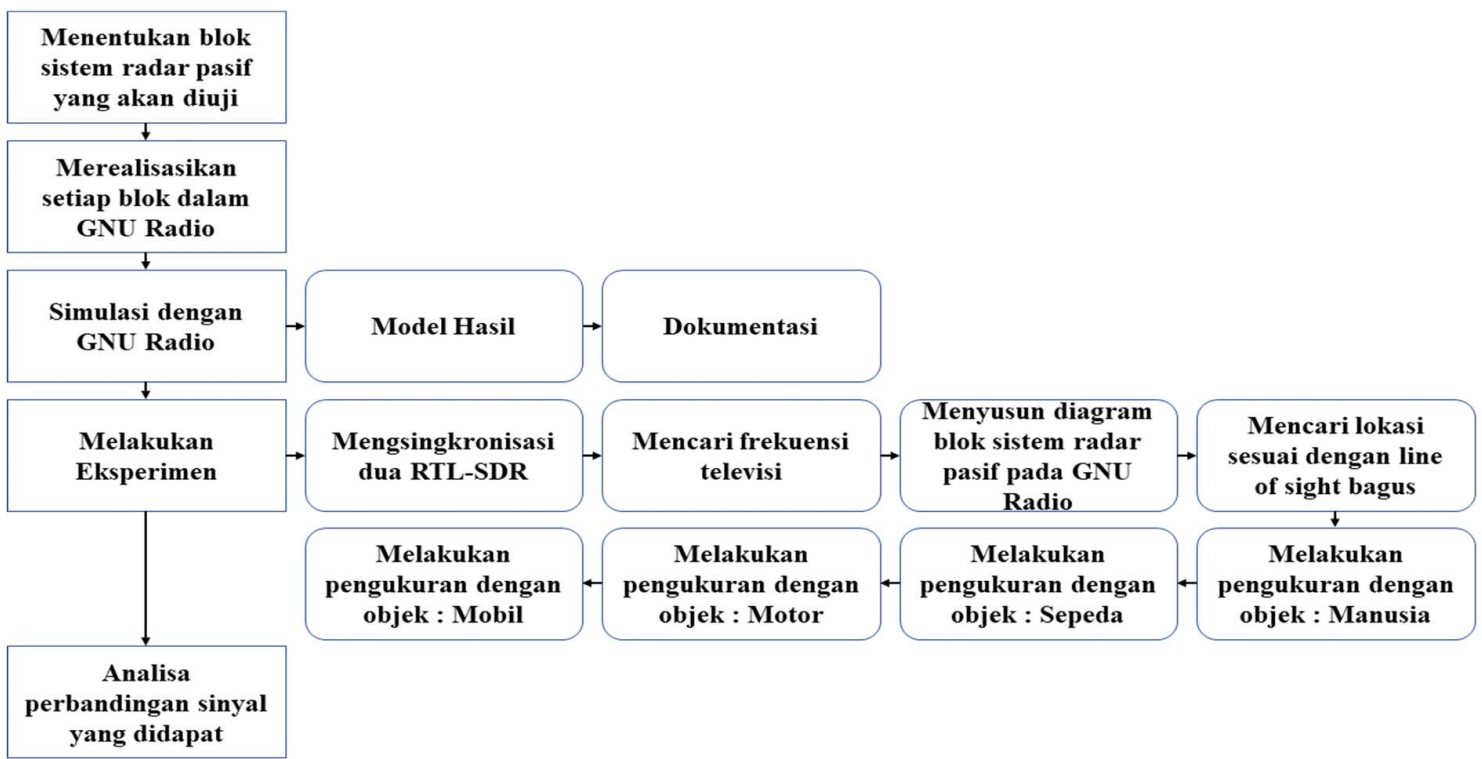

Gambar 3. Blok Perancangan Penelitian

Gambar 3 merupakan blok perancangan proyek pada penelitian ini. Blok sisi sebelah kiri merupakan garis besar penelitian dimulai dari perancangan blok yang akan digunakan dalam sistem radar pasif kemudian blok-blok direalisasikan pada GNU Radio dan disimulasikan untuk mengetahui model hasil akhir kemudian dilakukan eksperimen, dan terakhir dilakukan analisa perbandingan sinyal yang didapat. Blok sisi sebelah kanan merupakan penjelasan tahapantahapan yang akan dilakukan berdasarkan blok sebelah kiri.

\subsection{GNU Radio Simulasi}

GNU Radio dapat digunakan dengan perangkat eksternal untuk menciptakan Software Defined Radio (SDR). Pemrosesan sinyal baseband dari Digital Radio (DR) selalu diterapkan pada prosesor digital. Software Radio (SR) yang ideal secara langsung mengambil sample dari antenna output. SDR merupakan versi praktis dari SR (Sowjanya \& Satyanarayana, 2019). SDR didefinisikan sebagai radio di mana digitalisasi penerimaan dilakukan pada beberapa tahap hilir dari antena, biasanya setelah penyebaran lebar pita, penguat kebisingan rendah, dan konversi ke frekuensi yang lebih rendah pada tahap berikutnya - dengan proses terbalik terjadi untuk transmisi, digitalisasi. Pemrosesan sinyal digital yang tidak fleksibel dan blok fungsional yang dapat direkonfigurasi menentukan karakteristik radio (Tuttlebee, 2002).

GNU Radio merupakan alat pengembangan software yang gratis dan open source yang mengfasilitasi blok-blok signal-processing untuk mengimplementasikan SR (Anusha.S, 
Lahari.T.N, G.S.N.Bhavana, \& Pradeep.H.S, 2017). GNU Radio didasarkan pada kode Python dan $\mathrm{C}++$, dengan sifat open source yang memungkinkan pengguna menambahkan blok mereka sendiri, atau memodifikasi blok yang ada sesuai kebutuhan mereka. Blok kode yang diproduksi di GNU Radio Companion menghasilkan skrip Python, di mana semua parameter program disimpan (Patton, 2007).

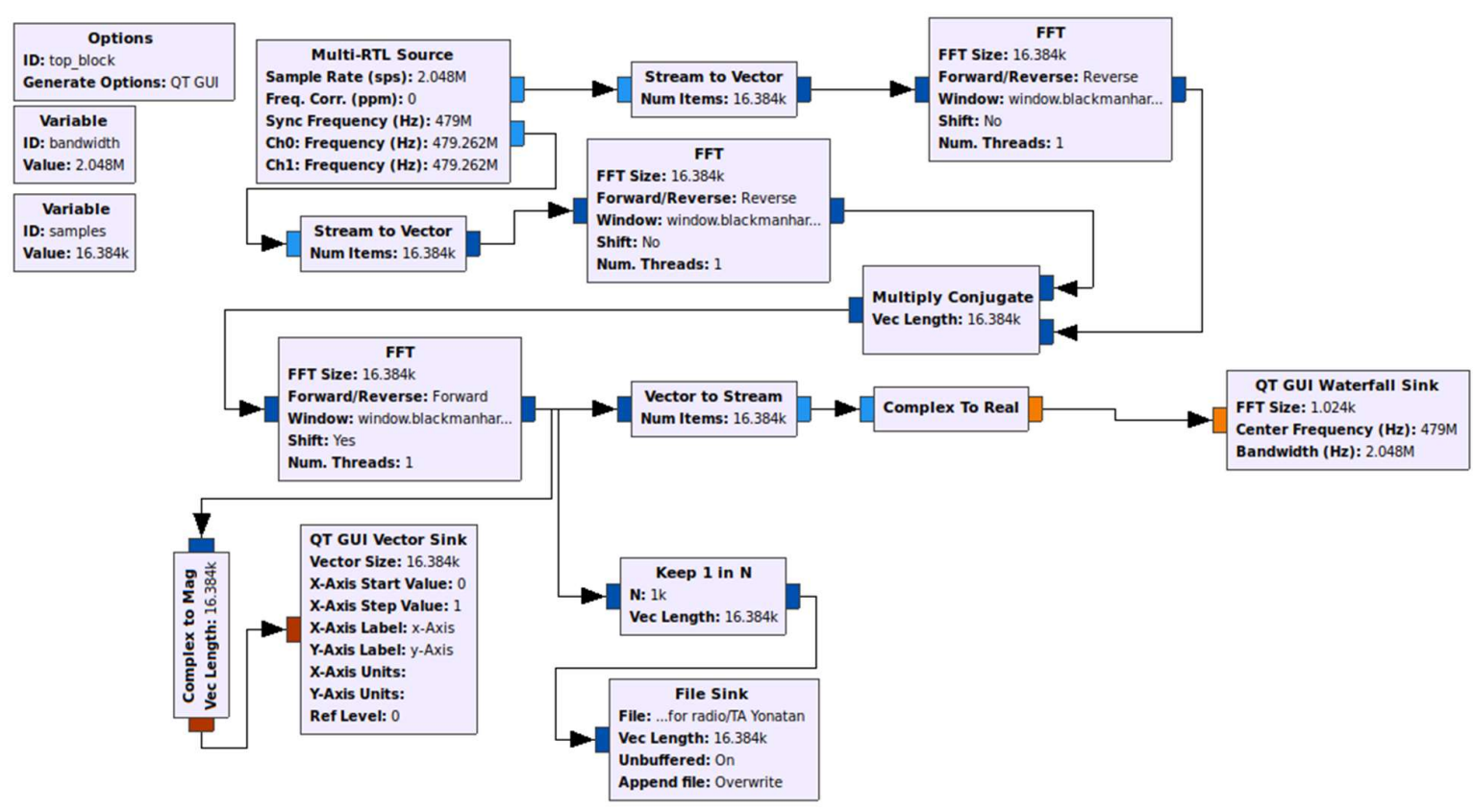

Gambar 4. Sistem Pasif Radar di GNU Radio

Pada Gambar 4 merupakan konfigurasi sistem radar pasif pada GNU Radio. Blok Multi-RTL Source di atas merupakan blok untuk memproses sinyal yang diterima oleh reference receiver dan surveillance receiver. Sinyal yang diterima diubah menjadi vektor dan diteruskan ke blok FFT. Di blok FFT ini sinyal yang berada dalam domain waktu diubah ke dalam domain frekuensi untuk bisa dilakukan cross-corelation. Setelah dilalakukan cross-corelation pada Multiply Conjugate, maka sinyal diubah lagi ke dalam domain waktu di dalam blok FFT lagi. Setelah itu sinyal diubah ke format awal melalui blok Vector to Stream dan ditampilkan sinyal hasil korelasi dengan GUI Waterfall Sink. Sinyal yang ditampilkan juga akan disimpal ke dalam File Sink untuk dilakukan analisa ke dalam Matlab untuk membandingkan percobaan dengan objek manusia, sepeda, motor, dan mobil.

\subsection{Kalibrasi}

Sebelum dilakukan pengukuran, sistem radar pasif yang dibuat dikalibrasi terlebih dahulu. Tujuan dari kalibrasi ini untuk melakukan sinkronisasi sinyal yang diterima. Kalibrasi dilakukan dengan cara meletakan objek sample di depan surveillance antenna receiver, menjalankan program GNU Radio, menjalankan ulang GNU Radio sampai ada perbedaan sinyal antara ada benda dan tidak ada benda. 

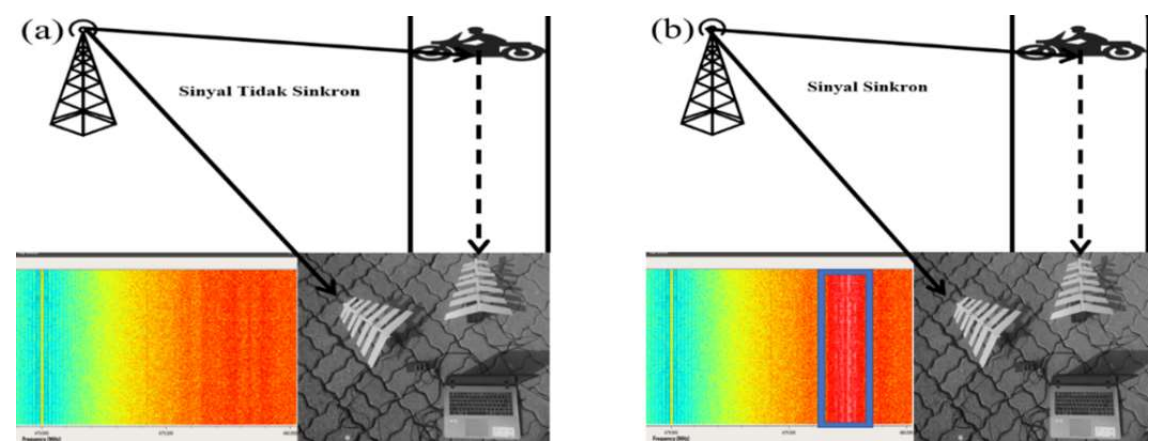

Gambar 5. Kalibrasi Sinyal yang Diterima. (a) Sinyal tidak Sinkron dan (b) Sinyal Sinkron

Dari Gambar 5, ditunjukan perbedaan antara sinyal sinkron dan tidak sinkron. Sinyal sinkron ditandakan saat ada garis putih bila ada objek pada radius surveillance receiver. Sinyal tidak sinkron saat tidak muncul garis putih meskipun ada objek pada radius surveillance receiver.

\subsection{Pengukuran}

Setelah kalibrasi dilakukan, maka eksperimen sistem radar pasif dapat dilaksanakan untuk mengukuran perbandingan kecepatan benda. Kecepatan benda ini dilambangkan dengan perumpamaan objek. Objek yang dimaksud seperti pada Gambar 8.

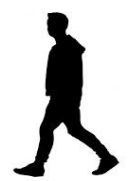

(a) Manusia

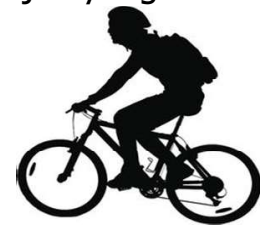

(b) Sepeda

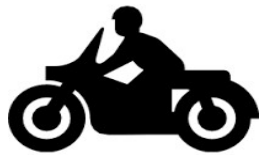

(c) Motor

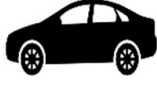

(d) Mobil

\section{Gambar 6. Target Bergerak}

Pada Gambar 6, target manusia melambangkan kecepatan lambat, sepeda melambangkan kecepatan sedang, motor melambangkan kecepatan cepat, mobil melambangkan kecepatan sangat cepat. Untuk menentukan besar delay yang dialamai benda bergerak, dilakukan pengukuran benda diam. Objek diam yang digunakan dalam pengukuran ini adalah motor yang ditunjukkan pada Gambar 7 berikut. Pengukuran benda diam ini dilakukan untuk dibandingkan deteksi motor diam dan deteksi motor bergerak. Motor dipilih karena RCS motor diasumsikan lebih besar dari manusia. 


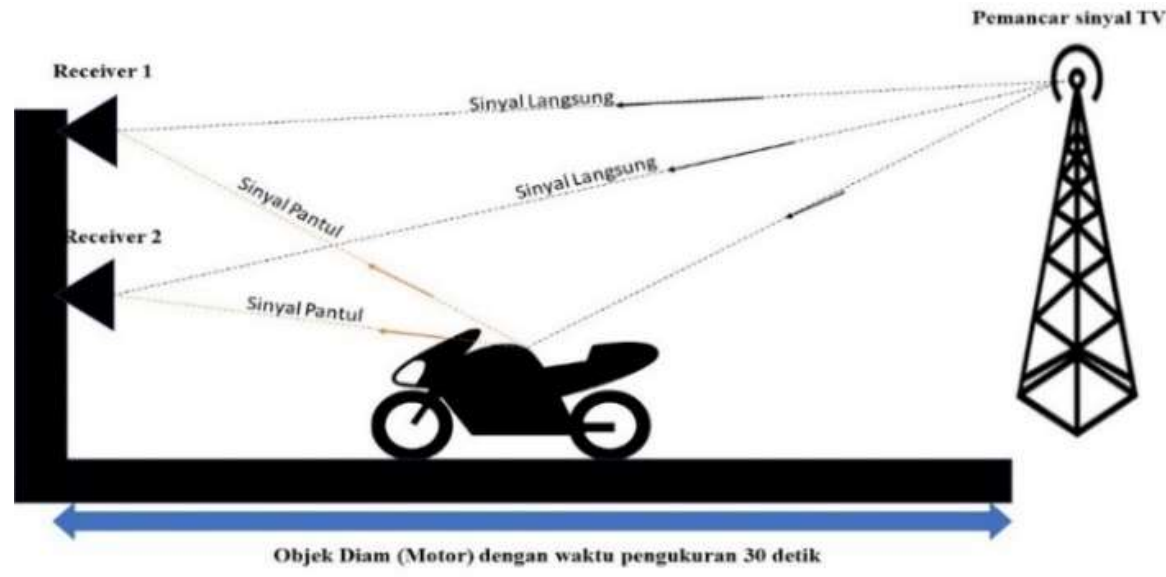

Gambar 7. Ilustrasi Pengukuran dengan Objek Diam

Objek bergerak yang digunakan dalam pengukuran ini adalah manusia, sepeda, motor, dan mobil yang ditunjukkan pada Gambar 8.

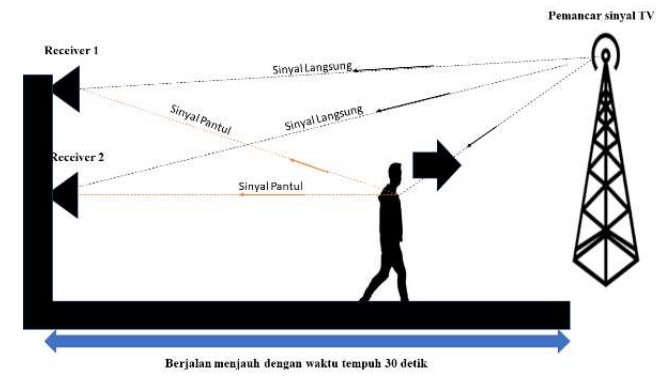

(a)

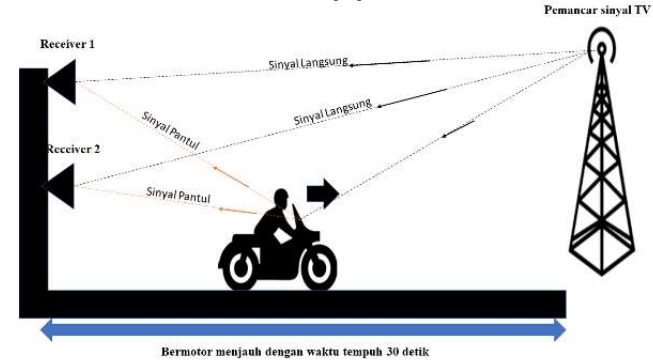

(c)

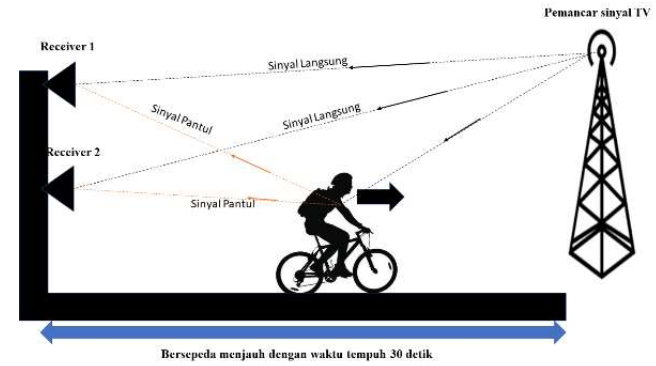

(b)

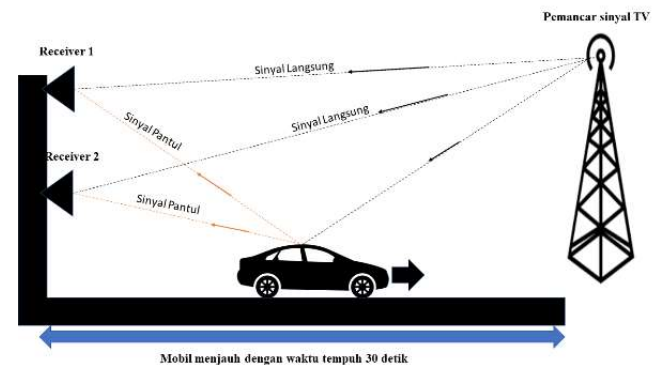

(d)

Gambar 8. Ilustrasi Pengukuran dengan Objek Bergerak

Pengukuran dilakukan dengan empat skenario, pertama dengan memeragakan manusia berjalan menjauhi antena receiver, kedua dengan sepeda menjauhi antena receiver, ketiga dengan motor menjauhi antena receiver, dan keempat dengan mobil menjauhi antena receiver. Semua skenario dilakukan selama 30 detik. Waktu tersebut diasumsikan masalah delay deteksi sudah terdeteksi dan dilakukan untuk penghematan memori untuk perekaman data. 


\section{HASIL \& ANALISIS}

\subsection{Waterfall pada GNU Radio}

Waterfall adalah keluaran hasil dari GNU Radio, waterfall ini berada pada frekuensi domain. Waterfall memiliki dua sumbu yaitu sumbu $x$ yang menyatakan frekuensi dan sumbu y yang meyatakan waktu. Pada waterfall ini dapat ditunjukkan pergerakan dari benda yang digambarkan berupa titik-titik putih pada frekuensi sumber. Berikut merupakan gambaran waterfallyang merupakan keluaran hasil GNU Radio sebelum diterjemahkan oleh software.

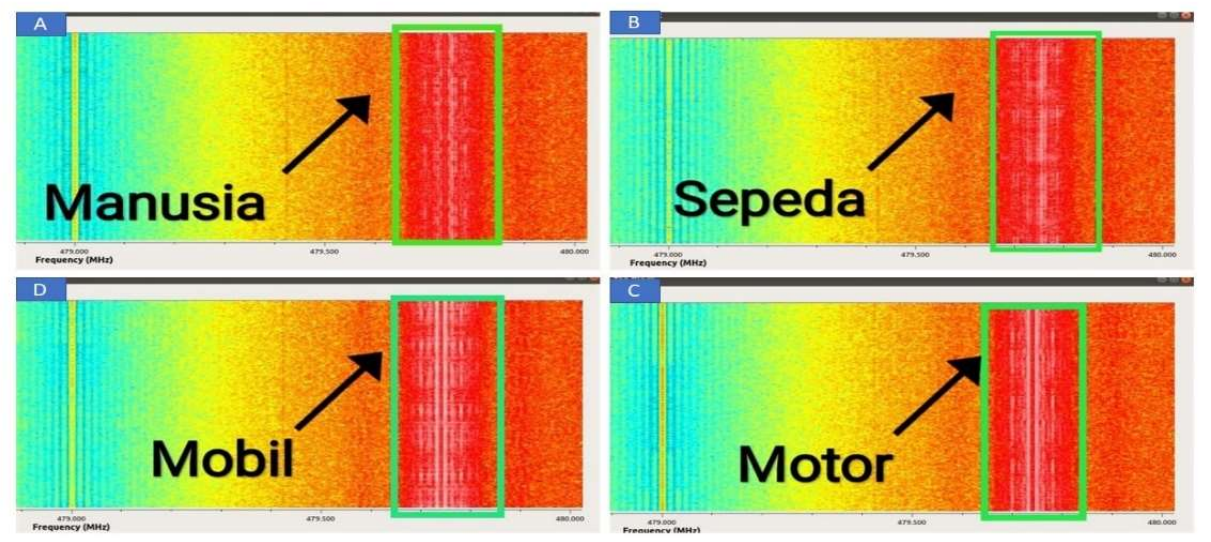

Gambar 9. Hasil Waterfall Keluaran GNU Radio

Pada Gambar 9, garis putih pada kotak hijau menunjukan ada objek atau benda bergerak pada radius surveillance receiver. Kecepatan pergerakan objek tersebut dapat terlihat dari perubahan ketebalan garis putih tersebut, semakin tebal menunjukan bahwa objek tersebut bergerak semakin cepat. Gambar tersebut kemudian diterjemahkan menggunakan software matlab untuk mendapatkan hasil yang lebih akurat.

\subsection{Cross-Correlation Peak Untuk Benda Diam}

Setiap pulse memiliki puncak yang merupakan korelasi silang antara dua buah sinyal yang diterima oleh reference receiver dan surveillance receiver. Besar korelasi menyatakan berapa banyak sinyal pantul (echo) yang memiliki kemiripan dengan sinyal asli (direct signa). Saat ada objek bergerak, sinyal echo akan mengalami delay. Untuk mengetahui berapa besar delay yang dialami, maka dilakukan pengukuran terhadap benda diam (motor). Korelasi silang dan delay dapat diketahui melalui Persamaan 3-6.

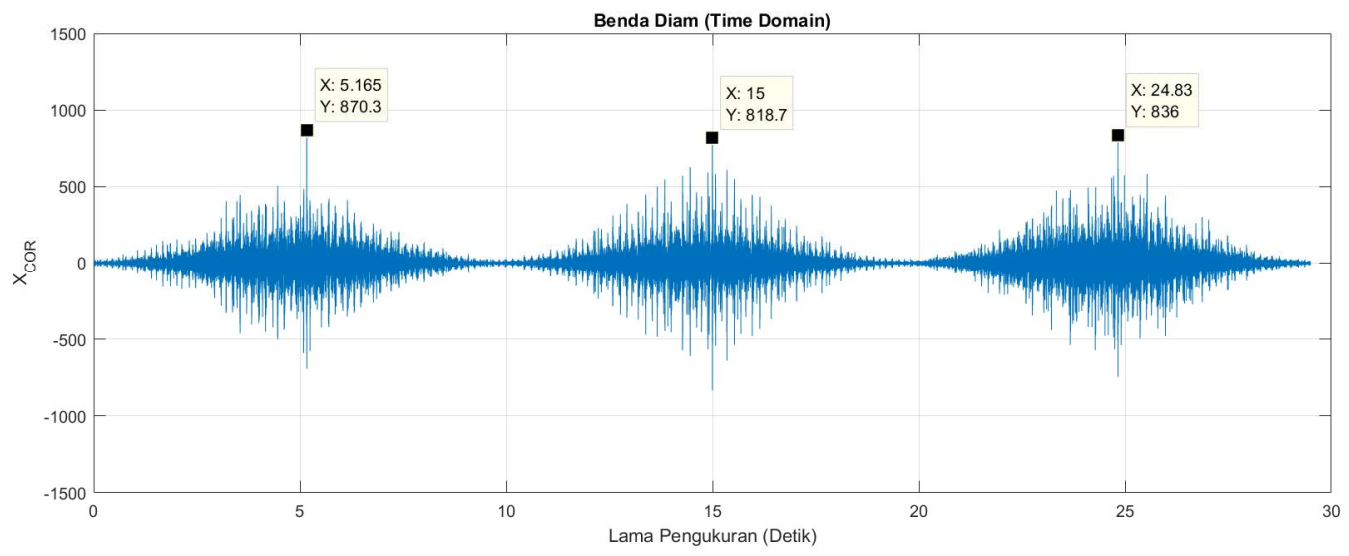

Gambar 10. Hasil Pengukuran Benda Diam 
Pada Gambar 10, ditunjukan puncak korelasi pulse pertama berada pada waktu 5,165 detik. Puncak korelasi pulse kedua berada pada waktu 15 detik. Puncak korelasi pulse ketiga berada pada waktu 24,83.

\subsection{Cross-Correlation Peak Untuk Benda Bergerak}

Pada Gambar 11, puncak korelasi pulse pertama berada pada waktu 5,357 detik. Puncak korelasi pulse kedua berada pada waktu 15,36 detik. Puncak korelasi pulse ketiga berada pada waktu 25,36 detik.

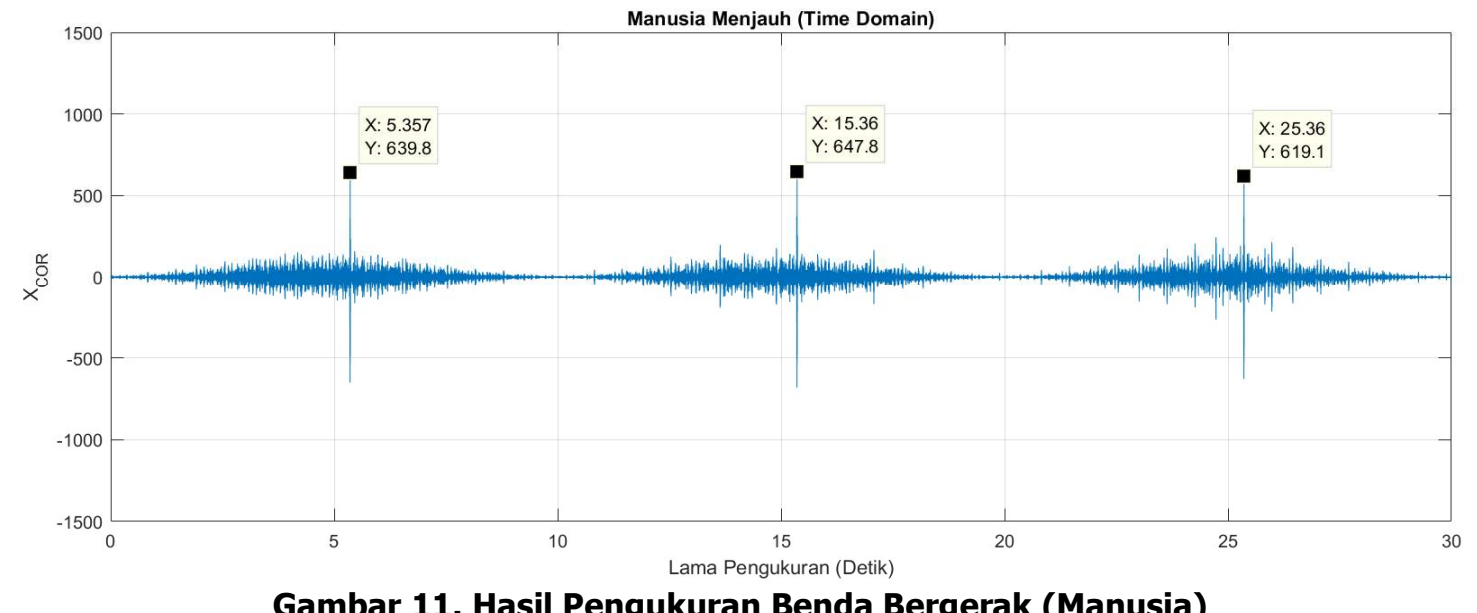

Gambar 11. Hasil Pengukuran Benda Bergerak (Manusia)

Setiap puncak korelasi mengalami delay sebesar 0,192 detik, 0,36 detik, dan 0,53 detik. Delay ini disebabkan oleh pergeseran korelasi yang diakibatkan dari pergerakan manusia yang menyebabkan terjadinya pergeseran waktu terima sinyal input-an yang dialami oleh surveillance receiver. Pada Gambar 12, puncak korelasi pulse pertama berada pada waktu 5,497 detik. Puncak korelasi pulse kedua berada pada waktu 15,5 detik. Puncak korelasi pulse ketiga berada pada waktu 25,5 detik. Setiap puncak korelasi mengalami delay sebesar 0,332 detik, 0,5 detik, dan 0,67 detik. Delay yang dialami oleh sepeda lebih besar dibanding delay yang dialami manusia karena pergerakan sepeda menjauhi surveillance receiver lebih cepat dibandingkan pergerakan manusia.

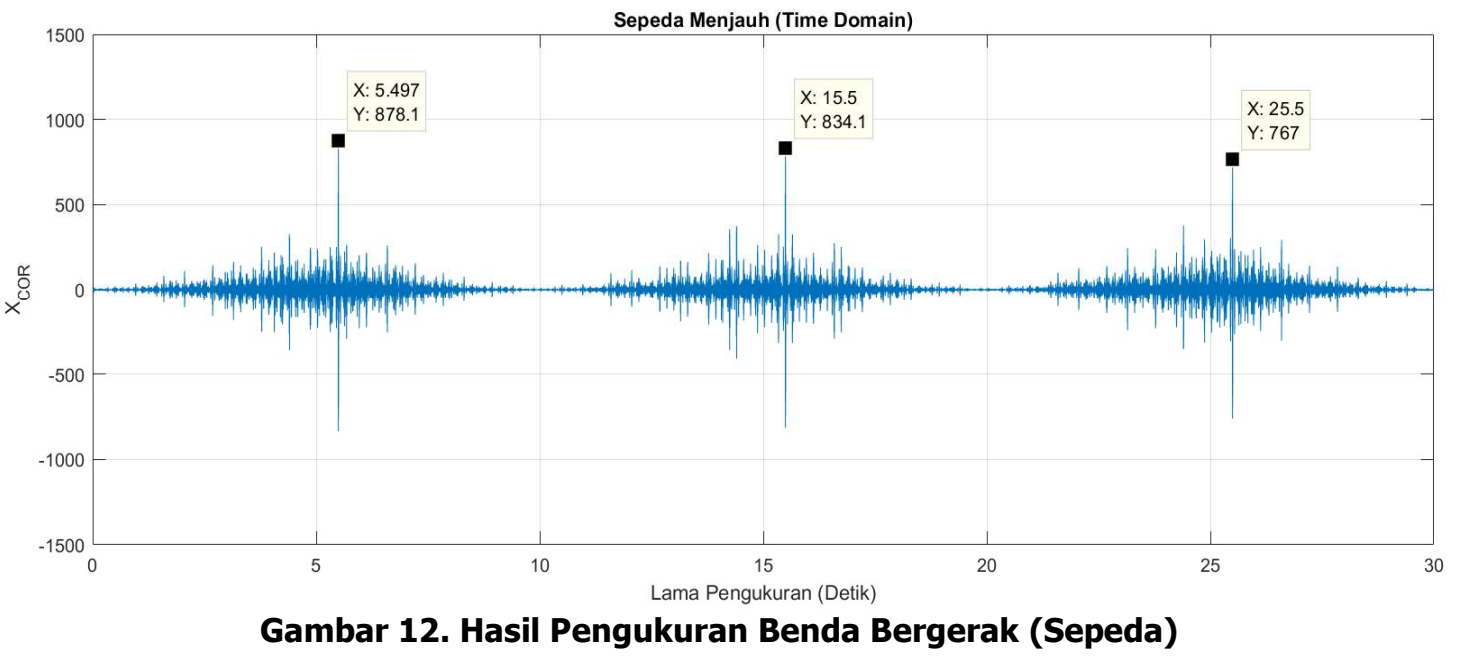

Pada Gambar 13, puncak korelasi pulse pertama berada pada waktu 5,687 detik. Puncak korelasi pulse kedua berada pada waktu 15,69 detik. Puncak korelasi pulse ketiga berada pada waktu 25,69 detik. Setiap puncak korelasi mengalami delay sebesar 0,422 detik, 0,69 detik, 
dan 0,86 detik. Delay yang dialami motor lebih besar dibanding delay yang dialami manusia dan sepeda karena kecepatan motor lebih cepat dibanding kecepatan manusia dan sepeda.

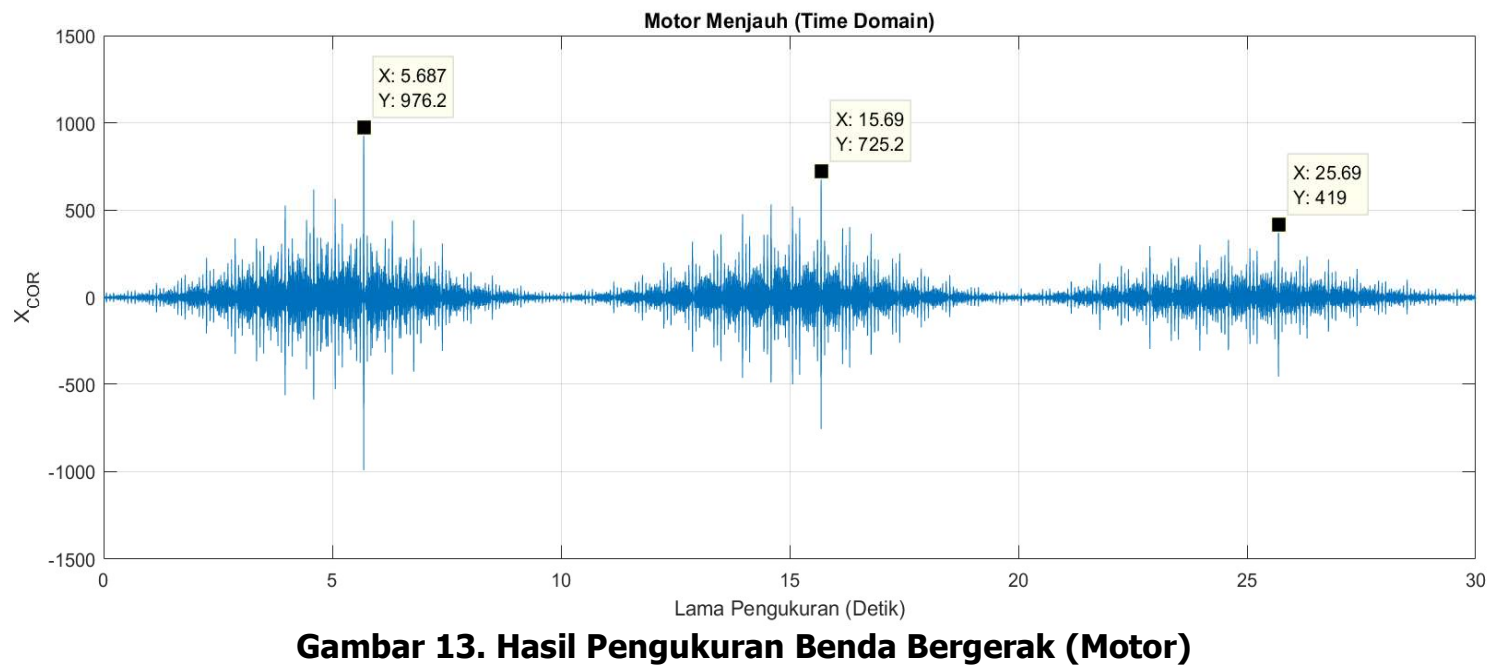

Pada Gambar 14 puncak korelasi pulse pertama berada pada waktu 5,703 detik. Puncak korelasi pulse kedua berada pada waktu 15,7 detik. Puncak korelasi pulse ketiga berada pada waktu 25,7 detik. Setiap puncak korelasi mengalami delay sebesar 0,538 detik, 0,7 detik, dan 0,87 detik. Delay pada mobil adalah yang paling besar. Ini disebabkan karena kecepatan mobil yang paling cepat menjauhi surveillance receiver.

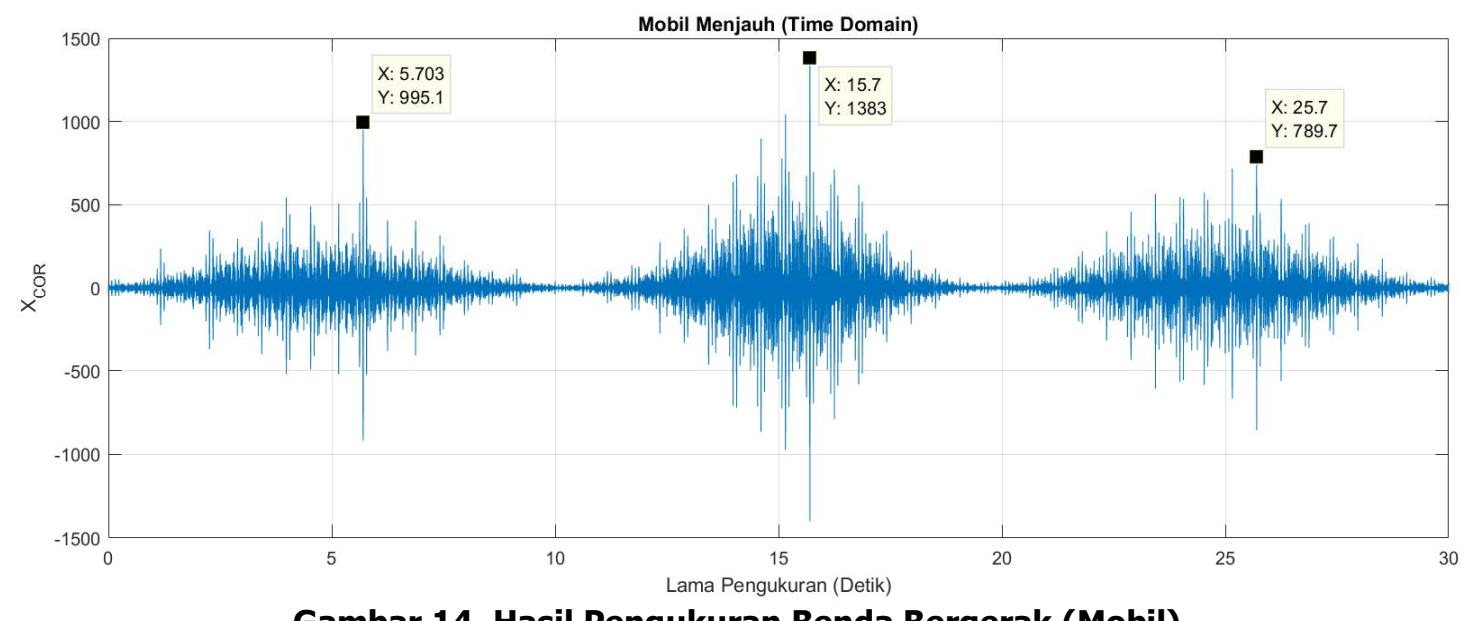

Gambar 14. Hasil Pengukuran Benda Bergerak (Mobil)

Tabel 1. Perbandingan Waktu Puncak Korelasi

\begin{tabular}{|c|c|c|c|c|c|c|}
\hline Objek & $\begin{array}{c}\text { Puncak } \\
\text { Korelasi 1 } \\
\text { (detik) }\end{array}$ & $\begin{array}{c}\text { Puncak } \\
\text { Korelasi 2 } \\
\text { (detik) }\end{array}$ & $\begin{array}{c}\text { Puncak } \\
\text { Korelasi } \\
\mathbf{3} \text { (detik) }\end{array}$ & $\begin{array}{c}\text { Delay } \\
\text { Gel. 1 } \\
\text { (detik) }\end{array}$ & $\begin{array}{c}\text { Delay } \\
\text { Gel. 2 } \\
\text { (detik) }\end{array}$ & $\begin{array}{c}\text { Delay } \\
\text { Gel. 3 } \\
\text { (detik) }\end{array}$ \\
\hline $\begin{array}{c}\text { Benda } \\
\text { Diam }\end{array}$ & 5,165 & 15 & 24,83 & - & - & - \\
\hline Manusia & 5,357 & 15,36 & 25,36 & 0,192 & 0,36 & 0,53 \\
\hline Sepeda & 5,497 & 15,5 & 25,5 & 0,332 & 0,5 & 0,67 \\
\hline Motor & 5,587 & 15,69 & 25,69 & 0,422 & 0,69 & 0,86 \\
\hline Mobil & 5,703 & 15,7 & 25,7 & 0,538 & 0,7 & 0,87 \\
\hline
\end{tabular}

Pada Tabel 1, membuktikan bahwa pergerakan suatu objek dapat menyebabkan delay pada puncak korelasi silang. Delay ini terjadi karena saat ada benda bergerak pada radius 
surveillance receiver, terjadi pergeseran waktu terima sinyal yang dialami oleh surveillance receiver. Semakin cepat benda menjauhi surveillance receiver, menyebabkan semakin besar juga jarak tempuh sinyal pantul dari objek ke surveillance receiver. Semakin besar jarak yang ditempuh sinyal pantul, semakin lama waktu yang dibutuhkan untuk sampai ke surveillance receiver, sementara waktu terima sinyal oleh reference receiver tidak berubah karena bebas objek. Perbedaan waktu terima ini yang menyebabkan pergeseran waktu puncak korelasi. Perbedaan waktu puncak korelasi ini yang disebut delay. Besar delay berbeda-beda berdasarkan kecepatan objek bergerak menjauhi surveillance receiver. Semakin cepat objek bergerak maka semakin besar delay yang terjadi.

\section{KESIMPULAN}

Hasil pengujian delay pada gelombang 1,2,3 untuk objek manusia adalah 0,192, 0,36 dan 0,53 detik, untuk objek sepeda adalah $0,332,0,5$ dan 0,67 , untuk objek motor adalah $0,422,0,69$ dan 0,86 detik, untuk objek mobil adalah 0,538, 0,7 dan 0,87 detik. Hasil yang didapatkan pada penelitian dengan pengukuran radar pasif adalah sistem radar pasif yang memanfaatkan frekuensi SDR menggunakan software GNU Radio dapat mendeteksi benda bergerak. Selain itu, dengan software tersebut sistem radar pasif dapat mendeteksi perbedaan kecepatan objek yang bergerak. Penerimaan sinyal sangat rentan terhadap interferensi noise. GNU Radio dapat mengimplementasikan radar pasif dalam domain frekuensi sedangkan software matlab menerjemahkannya dalam domain waktu. Perbedaan pada kecepatan pergerakan benda akan berbanding lurus dengan pergeseran letak puncak korelasi sedangkan kecepatan objek yang bergerak berbanding lurus dengan ketebalan garis putih pada waterfall.

\section{DAFTAR RUJUKAN}

Anusha, S., Lahari, T. N., Bhavana, G. S. N., \& Pradeep, H. S. (2017). GNU Radio based Real Time Data Transmission and Reception. International Research Journal of Engineering and Technology (IRJET), 4(7), 110-115.

Capria, A., Petri, D., Martorella, M., Conti, M., DalleMese, E., \& Berizzi, F. (2010). DVB-T passive radar for vehicles detection in urban environment. IEEE International Geoscience and Remote Sensing Symposium (pp. 3917-3920). Honolulu, HI, USA: IEEE.

Feng, W., Cherniak, G., \& Friedt, J. M. (2018). Software defined radio implementation of passive RADAR using low-cost DVB-T receiver. CNEAS. Sendai, Japan: Tohoku Univeristy.

Griffiths, H. (2014). Passive Bistatic Radar. University College London, London, UK: Elsevier Ltd.

Griffiths, H., \& Baker, C. J. (2017). An Introduction to Passive Radar. London: Artech House.

Heunis, S., Paichard, Y., \& Inggs, M. (2011). Passive radar using a sofware-defined radio platfrom and opensource software tools. IEEE RadarCon (RADAR) (pp. 879-884). Kansas City, MO, USA: IEEE. 
Hosking, R. H. (2011). Software Defined Radio Handbook. New Jersey: Penetk, Inc.

Liu, J., Li, H., \& Himed, B. (2015). Analysis of Cross-Correlation Detector for Passive Radar Applications. IEEE Radar Conference (RadarCon) Arlington, VA, USA: IEEE., (pp. 772776).

Mello, R. G., Sousa, F. R., \& junqueira, C. (2017). SDR-based radar-detectors embedded on tablet devices. SBMO/IEEE MTT-S International Microwave and Optoelectronics Conference (IMOC) Aguas de Lindoia, Brazil: IEEE, (pp. 1-5).

Patton, L. K. (2007). A GNU Radio Based Software Defined Radar. United States of America: Wrigth State Univeristy.

Proakis, J. G., \& Manolakis, D. G. (2007). Digital Signal Processing, 4th ed. New Jersey: Pearson Prentice Hall.

Rahman, H. (2019). Fundamental Principles of Radar. United States of America: Taylor and Francis Group.

Saputera, Y. P., Herdiana, D., Madinawati, H., Suksmono, A. B., \& Munir, A. (2015). Linear frequency modulated continuous wave radar using GNU radio and USRP. 1st International Conference on Wireless and Telematics (ICWT) Manado, Indonesia: IEEE, (pp. 1-6).

Skolnik, M. I. (1990). Radar Handbook. United States of America: McGraw-Hill.

Skolnik, M. I. (2002). Introduction to Radar System, 3rd ed. United States of America: McGrawHill.

Sowjanya, P., \& Satyanarayana, P. (2019). Real-Time Data Transfer Based on Software Defined Radio Technique using Gnu radio/USRP. International Journal of Engineering and Advanced Technology (IJEAT), 9(1), 279-288.

Tuttlebee, W. H. (2002). Software Defined Radio. England: Mobile VCE, Wiley \& Sons.

Willis, N. J. (2005). Bistatic Radar. United States of America: Scitech Publishing, inc. 